Farmer, E. D. (1954). J. gen. Microbiol. 11, 131-138.

\title{
Serological Subdivisions among the Lancefield Group H Streptococci
}

\author{
By E. D. FARMER \\ Pathology Laboratory, University of Cambridge
}

\begin{abstract}
SUMMARY: Seventeen members of Lancefield group $H$ streptococci were separated into two 'precipitin types', by a series of absorption precipitation experiments. Representative strains of Streptococcus sanguis types I and I/II were found to be serologically identical with the majority of the strains designated as members of group $\mathrm{H}$ types $\mathbf{2}$ and 1 respectively. $S$. sanguis type II was considered not to possess the group $\mathbf{H}$ group-specific substance.
\end{abstract}

The Lancefield group $\mathrm{H}$ streptococci were first identified by Hare (1935) who isolated them from apparently normal human throats. Two of the strains isolated by Hare were further investigated by Sherman (1937) and other members of this group were examined by Hehre \& Neill (1946), Dodd (1949) and Porterfield (1950). In 1946, Loewe, Plummer, Niven \& Sherman isolated a streptococcus, later called Streptoccocus sanguis (White, 1944), from the blood of $39 \%$ of patients with subacute bacterial endocarditis whom they examined. The characteristics of forty-two of these strains were investigated by Washburn, White \& Niven (1946), and by White \& Niven (1946). Although these workers were unable to isolate any strains of $S$. sanguis from the throats of normal patients, both Dodd (1949) and Porterfield (1950) considered that some strains of $S$. sanguis were members of Lancefield group H. Dodd (1949) claimed that the results of absorption precipitation experiments indicated the presence of at least five antigenically different types within the members of group H, and included $S$. sanguis types I and II within this group. Porterfield (1950), while agreeing that $S$. sanguis type I was a member of group $\mathrm{H}$, found that the third type, namely $S$. sanguis type I/II, also possessed the group $\mathbf{H}$ specific substance. He was, however, unable to demonstrate the group $\mathbf{H}$ antigen in $S$. sanguis type II. In view of the serological relationship of $S$. sanguis with Lancefield group $\mathrm{H}$ streptococci and the frequent isolation of the members of this group from the throats and mouths of normal patients (Farmer, 1953), it was considered of interest to investigate further the characteristics of the members of the group $\mathbf{H}$ streptococci. Accordingly, the cultural and biochemical characteristics of 24 strains were investigated, and seventeen strains were examined serologically by a series of absorption precipitation experiments.

\section{EXPERIMENTAL}

Source of organisms. Three of the strains examined came from the original collection of Prof. Hare, and were kindly provided by Dr Fry, together with 1 other strain; 2 other strains came from the blood of patients with subacute bacterial endocarditis and 1 from the mouth of one of these patients; single representatives of Streptococcus sanguis types I, II and I/II came from the 
National Collection of Type Cultures (NCTC), where they were numbered 7863, 7864 and 7865 respectively, and the remaining strains were isolated in Cambridge from the saliva or gingival sulci of apparently healthy patients.

Antigen extracts. The acid and formamide extracts of all strains were prepared from the growth in $50 \mathrm{ml}$. Hartley digest broth containing $1 \%$ glucose, using the methods suggested by Lancefield (1933) and Fuller (1938). Extracts were tested for ring-precipitate formation, in specially prepared tapering tubes modified from Lancefield (1938), using two group $\mathbf{H}$ grouping sera, one prepared by Dr Fry with the strain Blackburn and labelled $\mathbf{H}_{4}$, and the other prepared in the Burroughs Wellcome Research Laboratories and labelled no. 6244. Only those extracts which formed good precipitates at room temperature in about $10 \mathrm{~min}$. were regarded as being positive.

Sera. The sera used in the absorption precipitation experiments were prepared in rabbits. Immunization was by means of formalin-killed suspensions (Lancefield, 1983) with four or six series of four injections of $1 \mathrm{ml}$. each, or live suspensions starting with small doses of $0.1 \mathrm{ml}$. and doubling the dose on alternate days up to $1.6 \mathrm{ml}$. on the 9 th day. Suspensions of organisms were made to have the opacity of an $\mathbf{1 8} \mathrm{hr}$. glucose broth culture. Rabbits injected with killed suspensions were bled on the 5th day after the last injection, while those injected with live organisms were bled on the 7th day after the last injection. The sera which formed satisfactory precipitates when tested with the extracts of the homologous strain were kept and stored at $-20^{\circ}$ without preservative.

The method used for the absorption of the sera was modified from that of Lancefield (1933). The sera were mixed with an equal volume of packed heatkilled cells and incubated in a water-bath at $37^{\circ}$ for three-quarters of an hour. Those sera which formed precipitates after absorption when tested against any of the extracts used in the experiment were re-absorbed and re-tested. All absorptions were controlled by parallel absorptions using the cells of a heterologous Lancefield group $\mathrm{G}$ strain. The cultural and biochemical characteristics were investigated by the methods reported elsewhere (Farmer, 1951).

\section{RESULTS}

\section{Serological}

Extracts of the 17 strains formed strong precipitates when tested with the 2 group $\mathrm{H}$ grouping sera. Sera prepared in rabbits with 6 of these strains showed no cross-reactions with extracts of members of Lancefield groups $\mathbf{A}$ to $\mathrm{K}$ and $\mathrm{L}$ to $\mathrm{O}$, but showed strong reactions with those of known members of group $\mathbf{H}$.

Preliminary absorption precipitation experiments with some of the sera indicated that not all the strains considered were serologically identical. To investigate these results the sera prepared from 6 group $\mathrm{H}$ strains and the 2 group $\mathbf{H}$ grouping sera were absorbed with most of the available group $\mathbf{H}$ strains and the resulting absorbed sera were then tested against the acid extracts of the 17 strains. It was found that the sera prepared with the strains 
labelled 187 and Challis and the Blackburn antiserum $\left(\mathrm{H}_{4}\right)$ were completely absorbed by 7 strains, namely 187, Challis, Blackburn, Hatchman, 14, Morrison and Channon (Table 1). These strains, together with 5 others whose extracts reacted in a similar way, were classified as group $\mathbf{H}$ type 1 . After absorption with the strains $B$ and 44 these sera still formed good precipitates with the extracts of the above 12 strains and accordingly the strains $B$ and 44, together with three others, were classified as group $\mathbf{H}$ type 2 .

Table 1. A summary of the results of absorption precipitation experiments using sera prepared with the group $\boldsymbol{H}$ streptococci labelled Blackburn, Challis and 187.

\begin{tabular}{|c|c|c|c|}
\hline \multirow[b]{2}{*}{$\begin{array}{l}\text { Acid extracts } \\
\text { of streptococci }\end{array}$} & \multicolumn{3}{|c|}{$\begin{array}{l}\text { Sera prepared with group H streptococci Blackburn, } \\
\text { Challis and } \mathbf{1 8 7}\end{array}$} \\
\hline & Unabsorbed & $\begin{array}{c}\text { Absorbed by } \\
\text { group H type } 1 \\
\text { strains } \\
\text { (7 strains) }\end{array}$ & $\begin{array}{c}\text { Absorbed by } \\
\text { group H type } 2 \\
\text { strains } \\
\text { (2 strains) }\end{array}$ \\
\hline $\begin{array}{l}\text { Group H type } 1 \\
\text { (12 strains) }\end{array}$ & $+t+$ & - & ++ \\
\hline $\begin{array}{l}\text { Group } H \text { type } 2 \\
\text { (5 strains) }\end{array}$ & +++ & - & - \\
\hline
\end{tabular}

Table 2. A summary of the results of absorption precipitation experiments using serum prepared with the group $\boldsymbol{H}$ strain labelled $\boldsymbol{H}$ atchman

Serum prepared with strain Hatchman

\begin{tabular}{|c|c|c|c|c|}
\hline & \multicolumn{4}{|c|}{ Serum prepared with strain Hatchman } \\
\hline Acid extracts & Unabsorbed & $\begin{array}{c}\text { Absorbed with } \\
\text { group H type } 1 \\
\text { strains } \\
\text { (excluding } \\
\text { Blackburn, } \\
\text { Challis and } \\
\text { Channon) }\end{array}$ & $\begin{array}{c}\text { Absorbed with } \\
\text { strains } \\
\text { Blackburn, } \\
\text { Challis and } \\
\text { Channon }\end{array}$ & $\begin{array}{c}\text { Absorbed with } \\
\text { Group H, type } 2 \\
\text { strains B \& 44 }\end{array}$ \\
\hline $\begin{array}{l}\text { Group } H \text {, type } 1 \\
\text { (excluding strains } \\
\text { Blackburn, Challis } \\
\text { and Channon) }\end{array}$ & +++ & - & +++ & +++ \\
\hline $\begin{array}{l}\text { Blackburn, Challis } \\
\text { and Channon }\end{array}$ & ++ & - & - & - \\
\hline Group $\mathrm{H}$ type 2 & $+t+$ & - & - & - \\
\hline
\end{tabular}

Not all the sera prepared with the type 1 strains produced the same results as each other. That prepared with the strain Hatchman was completely absorbed by 4 type 1 strains, but was incompletely absorbed by the strains Blackburn, Challis and Channon (see Table 2). The acid extracts of these 3 strains differed in their reactions from those of the other type 1 strains in that they failed to form precipitates with this serum after it had been absorbed by the type 2 strains, $B$ and 44 . The serum prepared with strain 14 produced similar results to those recorded in Table 2, but in this case the extracts of strains Blackburn, Challis and Channon also formed strong reactions after the serum had been absorbed with the type 2 strains $B$ and 44 . 
The sera prepared with two of the strains classified as type 2 , namely $\mathbf{B}$ and 44, were each completely absorbed by the cells of these 2 strains and also by the cells of the 3 others previously classified as type 2 (see Table 3 ). These 2 sera did not, however, show identical reactions when absorbed with the type 1 cells. Anti-B serum was incompletely absorbed by all the type 1 cells

Table 3. A summary of the results of absorption precipitation experiments using the serum prepared with group $\boldsymbol{H}$ type 2 streptococci labelled $\boldsymbol{B}$.

\begin{tabular}{|c|c|c|c|}
\hline & \multicolumn{2}{|c|}{ Serum prepared with strain $B$} & \\
\hline $\begin{array}{c}\text { Acid } \\
\text { extracts }\end{array}$ & Unabsorbed & $\begin{array}{c}\text { Absorbed } \\
\text { with group } \\
\text { H type } 1 \\
\text { strains } \\
\text { (7 strains) }\end{array}$ & $\begin{array}{c}\text { Absorbed } \\
\text { with group } \\
\text { H type } 2 \\
\text { strains } \\
\text { (5 strains) }\end{array}$ \\
\hline $\begin{array}{l}\text { Group } H \text { type } 1 \\
\text { (12 strains) }\end{array}$ & $+t+$ & - & - \\
\hline $\begin{array}{l}\text { Group } H \text { type } 2 \\
B \text { and } 44\end{array}$ & $+t+$ & ++ & - \\
\hline 89,54 and $K$ & ++ & + & - \\
\hline
\end{tabular}

while the anti-44 serum, which did not form very strong reactions even when unabsorbed, was apparently completely absorbed by 4 of the 7 type 1 strains tested, namely Blackburn, Challis, Channon and Morrison. The Burroughs Wellcome serum, prepared with a strain labelled $\mathrm{CN}$ 880, was completely absorbed by the cells of all the group $\mathbf{H}$ strains classified into both types 1 and 2.

The separation of strains into types 1 and 2 was not so clearly defined when formamide extracts of cells were used. The formamide extracts of type 1 cells failed to react with the homologous sera after absorption with the type 2 cells, but those of the members of type 2 still reacted with the absorbed homologous sera in the same way as their acid extracts. In all cases lowering the temperature of formamide extraction to $134^{\circ}$ or $100^{\circ}$ failed to affect the results, but generally reduced the quality of the precipitates formed with the unabsorbed and the absorbed sera.

Incubation of the acid extracts of 4 members of type 1 and 2 of type 2 with $2 \%, 4 \%$ or $8 \%(\mathrm{v} / \mathrm{v})$ trypsin (Allen \& Hanburys) over a period of $24 \mathrm{hr}$. (method of Lancefield, 1934), failed to alter the reaction with any of the absorbed sera.

\section{Relationship of Streptococcus sanguis to Lancefield group $\boldsymbol{H}$ Streptococci}

When acid extracts of the available strains of the 3 types of Streptococcus sanguis were tested against the group $H$ antisera, $S$. sanguis type I and typeI/II both formed strong precipitates (Table 4). S. sanguis type II formed moderately strong precipitates with most of these sera but, as found by Porterfield (1950), it did not react with the Burroughs Wellcome serum or with that prepared with the strain Challis. With the previously described absorbed group $\mathbf{H}$ sera (Tables $1,2 \& 3$ ), the extract of $S$. sanguis type I showed the same reactions as the group $\mathrm{H}$ type 2 strains, while $S$. sanguis type I/II reacted in the same way 
as the majority of the group $\mathbf{H}$ type 1 strains. All the sera prepared with the group $\mathrm{H}$ type 1 strains were completely absorbed by the cells of $S$. sanguis type I/II, and those prepared with group $H$ type 2 strains were completely absorbed by the cells of $S$. sanguis type I. $S$. sanguis type II did not remove any precipitating antibodies from these sera except those for its own antigens.

Table 4. The precipitates formed when the acid extracts of the three types of Streptococcus sanguis were tested against sera prepared with members of Lancefield group $\boldsymbol{H}$ streptococci

Serum prepared with the following strains

\begin{tabular}{|c|c|c|c|c|c|c|c|c|}
\hline $\begin{array}{c}\text { Acid } \\
\text { extracts }\end{array}$ & $\begin{array}{c}\text { Burroughs } \\
\text { Wellcome } \\
\text { group H }\end{array}$ & Challis & Blackburn & $\begin{array}{l}\text { Hatch- } \\
\text { man }\end{array}$ & 187 & 14 & B & 44 \\
\hline $\begin{array}{l}S . \text { sanguis } \\
\text { type I }\end{array}$ & ++ & +++ & +++ & +++ & +++ & +++ & +++ & +++ \\
\hline $\begin{array}{l}\text { S. sanguis } \\
\text { type II }\end{array}$ & - & - & ++ & ++ & $++t$ & +++ & ++ & ++ \\
\hline $\begin{array}{l}\text { S. sanguis } \\
\text { type I/II }\end{array}$ & ++ & $++t$ & +++ & +++ & +++ & +++ & +++ & +++ \\
\hline
\end{tabular}

Sera were prepared with the three types of Streptococcus sanguis and the results of the absorption precipitation experiments of Washburn, White \& Niven (1946) were confirmed. Reciprocal absorption precipitation experiments were then carried out with the group $\mathbf{H}$ strains. The results (Table 5) confirmed the identity of $S$. sanguis type $\mathbf{I}$ with the members of group $\mathrm{H}$ type 2 and of $S$. sanguis type I/II with the majority of the members of group $\mathbf{H}$ type 1 . The $S$. sanguis type II antiserum showed a poor reaction with its own extract after absorption with group $\mathbf{H}$ type $\mathbf{1}$ cells. The extracts of $S$. sanguis types II and I/II and the group $\mathbf{H}$ type $\mathbf{I}$ strains produced good reactions with this serum after absorption with the group $\mathbf{H}$ type 2 cells.

\section{Cultural and biochemical tests}

The results of cultural and biochemical tests on the 24 group $\mathbf{H}$ streptococci (Farmer, 1953) were very similar to those reported by Porterfield (1950). Owing to the disproportionate numbers of strains in the two types, it was considered of little value to record the characteristics of each type separately, but no one characteristic, nor combination of characteristics, could be found to be related to the serological subdivisions.

\section{DISCUSSION}

From the results of the absorption precipitation experiments with 17 strains of Lancefield group $\mathbf{H}$ streptococci, it was apparent that this group of organisms was not serologically homogeneous. Many of the strains examined, particularly those isolated from mouths, formed unstable suspensions, and it was not possible to test the results by absorption agglutination experiments. It seemed probable, however, that the serological differences between the strains 


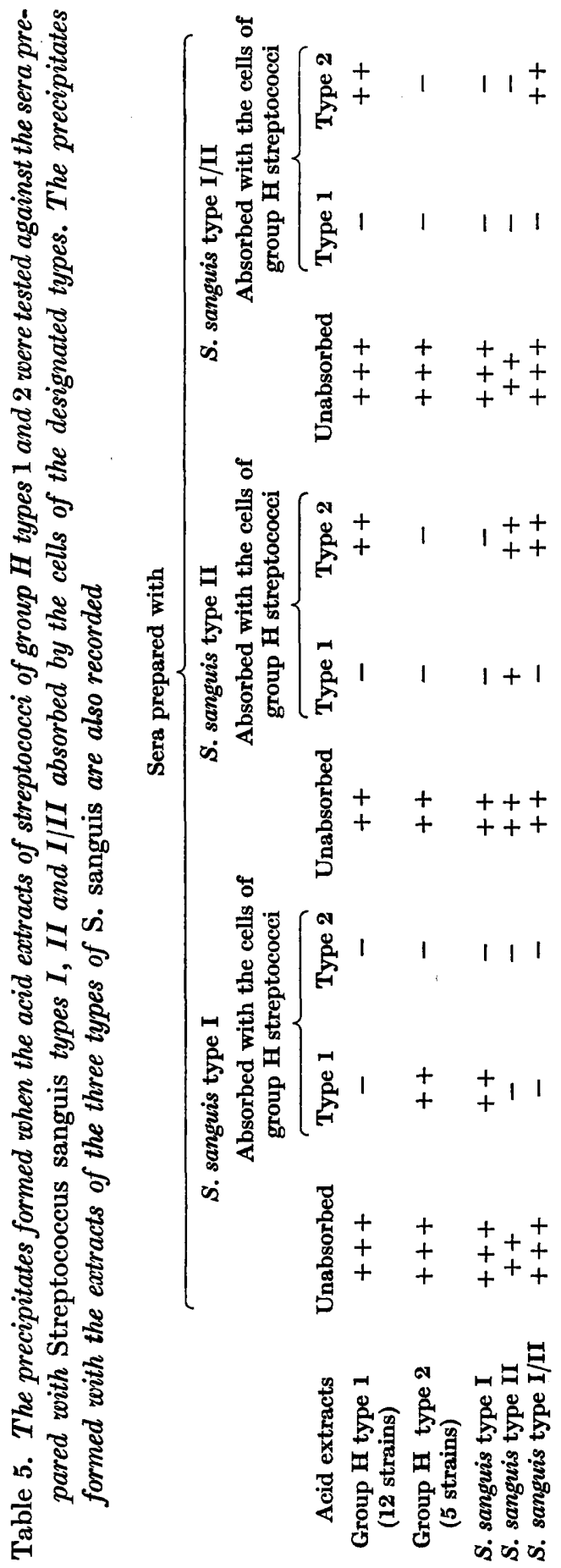


examined was due to the presence of different type antigens, and accordingly the strains were divided into two types.

Not all the strains classified into each type showed exactly similar results with each of the sera used. The three classical strains, Blackburn, Challis and Channon, did not seem to possess a type 1 antigen identical with that possessed by the other members classified within this type, but although they reacted in different ways from the other type 1 strains with some of the sera used, there did not seem to be sufficient evidence to classify them into a third type. Other similar differences in reactions were seen among the strains at present allocated to the two types; further investigations may therefore reveal further divisions among the streptococci sharing the group $\mathbf{H}$ antigen. The failure of trypsin to affect the extracts of selected members of each type suggests that the type antigens are probably not proteins.

The extracts of four other streptococci not included in these results, formed moderately good precipitates with most of the group $\mathbf{H}$ type $\mathbf{1}$ antisera, but, because they failed to react with either the type 2 antisera or the Burroughs Wellcome group $\mathrm{H}$ grouping serum, they were considered not to possess the group $\mathbf{H}$ antigen. It is of interest to note that they were able to absorb the serum prepared with Streptococcus sanguis type II completely and although reciprocal absorption precipitation experiments were not carried out, it is probable that they shared some of the antigens present in this strain of $S$. sanguis. The reciprocal absorption precipitation tests using sera prepared with the group $H$ streptococci and the strains of $S$. sanguis confirmed the results of Porterfield (1950) that $S$. sanguis type I and I/II possessed the group $H$ antigen. The results also showed that $S$. sanguis types I and I/II shared the type antigens of the majority of those strains allocated to group $\mathbf{H}$ types $\mathbf{2}$ and 1 respectively. The failure of $S$. sanguis type II to remove the precipitating antibodies from any of the absorbed group $\mathrm{H}$ sera, excepting those for its own extract, indicated that it probably did not possess the group $\mathrm{H}$ antigen.

It was found from the results of the investigation of the cultural and biochemical characteristics of 194 streptococci (Farmer, 1951, 1953), that the possession of no one physiological characteristic was a definite indication that the strain was a member of Lancefield group $\mathbf{H}$, but that a high proportion of the members of this group possessed a combination of characteristics not usually found among the members of other Lancefield groups. This combination of characteristics was found by White \& Niven (1946) to be possessed also by Streptococcus sanguis and included the ability to hydrolyse arginine, to grow on blood agar in the presence of $40 \%(\mathrm{v} / \mathrm{v})$, bile, to decolorize and grow in the presence of $0 \cdot 1 \%$ methylene blue in milk, to produce a detectable dextran from sucrose and to ferment inulin but not raffinose. There was no apparent relationship between the serological differences among the group $\mathbf{H}$ streptococci and their cultural and biochemical characteristics.

The writer wishes to thank Prof. H. R. Dean who kindly provided the laboratory facilities which made this work possible, and also Dr R. M. Fry and his staff at the Public Health Laboratory Service, Cambridge, for their help and encouragement. Most of the work was done while in receipt of a full-time grant from the Nuffield Foundation. 


\section{REFERENCES}

Dopd, R. L. (1949). Serological relationship between streptococcus group $H$ and Streptococcus sanguis. Proc. Soc. exp. Biol. N.Y. 70, 598.

FARMer, E. D. (1951). Thesis: The streptococci of the mouth. University of Liverpool.

FARMer, E. D. (1953). The streptococci of the mouth and their relationship to subacute bacterial endocarditis. Proc. roy. Soc. Med. 46, 201.

Fuller, A. T. (1938). The formamide method for the extraction of polysaccharides from haemolytic streptococci. Brit. J. exp. Path. 19, 130.

HARE, R. (1935). The classification of haemolytic streptococci from the nose and throats of normal human beings by means of precipitin and biochemical tests. J. Path. Bact. 41, 499.

Hehre, E. J. \& NeiLL, J. M. (1946). Formation of serologically reactive dextrans by streptococci from subacute bacterial endocarditis. J. exp. Med. 83, 147.

LANCEFIELD, R. C. (1933). A serological differentiation of human and other groups of haemolytic streptococci. J. exp. Med. 57, 571.

LANCEFIELD, R. C. (1934). A serological differentiation of specific types of bovine haemolytic streptococci (group B). J. exp. Med. 59, 441 .

LANCEFIELD, R. C. (1938). Two serological types of group B haemolytic streptococci with related, but not identical, type specific substances. J. exp. Med. 67, 25.

Loewe, L., Plummer, N., Niven, C. F. \& Sherman, J. M. (1946). Streptococcus s.b.e. in subacute bacterial endocarditis. J. Amer. med. Ass. 130, $25 \%$.

Porterfield, J. S. (1950). Classification of the streptococci of subacute bacterial endocarditis. J. gen. Microbiol. 4, 92.

Sherman, J. M. (1937). Streptococci. Bact. Rev. 1, 1.

Washburn, M. E., White, J. C., \& Niven, C. F. (1946). Streptococcus s.b.e.: immunological characteristics. J. Bact. 51, 723.

White, J. C. (1944). Reported in White, J. C. \& Niven, C. F. (1946) from thesis: Streptococci from subacute bacterial endocarditis. Cornell University, N.Y.

White, J. C. \& Niven, C. F. (1946). Streptococcus s.b.e.: a streptococcus associated with subacute bacterial endocarditis. J. Bact. 51, 717.

(Received 21 December 1953) 